\title{
Assessment of Eyebright (Euphrasia Officinalis L.) Extract Activity in Relation to Human Corneal Cells Using In Vitro Tests
}

\author{
Roman Paduch ${ }^{1}$, Anna Woźniak ${ }^{2}$, Piotr Niedziela ${ }^{3}$, Robert Rejdak ${ }^{2}$ \\ ${ }^{1}$ Department of Virology and Immunology, Maria Curie-Sklodowska University Faculty of Biology and Biotechnology, Lublin, Poland \\ ${ }^{2}$ Department of General Ophthalmology, Medical University of Lublin, Lublin, Poland \\ ${ }^{3}$ Department of Surgery, District Railway Hospital, Lublin, Poland
}

Background: Euphrasia officinalis L. is an herb traditionally used in folk medicine, mainly in the treatment of eye disorders.

Aims: The present study analyzed the activity of three extracts of $E$. officinalis L. (ethanol, ethyl acetate and heptane) on cultured human corneal epithelial cells (10.014 pRSV-T).

Study Design: In vitro study.

Methods: Toxicity, free radical scavenging activity and the immunomodulatory effects of the extracts were tested using the thiazolyl blue tetrazolium bromide (MTT) or Neutral Red, 2,2-Diphenyl1-picrylhydrazyl (DPPH) and ELISA tests, respectively. Moreover, nitric oxide levels and cytoskeleton architecture were analyzed after corneal cell incubation with the plant extracts.

Results: We show that the biological effect depended on both the concentration and the extraction solvent used. Heptane extracts, distinct from those in ethanol and ethyl acetate, were toxic to $10.014 \mathrm{pRSV}-\mathrm{T}$ cells at low concentrations $(25 \mu \mathrm{g} / \mathrm{mL})$ and did not demonstrate free radical scavenging effects. All tested extracts decreased pro-inflammatory cytokine expression (IL-1 $\beta$, IL-6 and TNF- $\alpha$ ) and also anti-inflammatory IL-10 expression by human corneal cells when the extracts were added to the cell culture medium for $24 \mathrm{~h}$.

Conclusion: In conclusion, we show that the promising effects of the application of E. officinalis L. preparations as a supplementary therapy for eye disorders are associated with the ethanol and ethyl acetate extracts, not the heptane extract. (Balkan Med J 2014;31:29-36).

Key Words: Cytotoxicity, Euphrasia officinalis extracts, human corneal cells, immunomodulation, reactive oxygen species scavenging effect
Herba Euphrasiae (Scrophulariaceae), commonly known as eyebright grass, is a composition of very similar plant species, broadly defined as Euphrasiae officinalis L., which are widely used in folk medicine and homeopathy $(1,2)$. E. officinalis L. is an annual, herbaceous, semi-parasitic plant which exhibits numerous biological activities, including anti-inflammatory, antioxidant, antimicrobial, anticancer, antifungal, antiviral, hypotensive, hapatoprotector, anti-epileptic, and anticatarrhal activities (3-8). In traditional medicine, E. officinalis L. has also been effectively used for the treatment of eye disorders like conjunctivitis, hordeolum, etc. $(1,5,9)$. Eye drops made from E. officinalis L. are considered to be useful and safe in the treatment of ocular allergy symptoms (10). Folk medicine commonly uses eyebright aqueous extracts to treat eye disorders. Additionally, methanolic extracts of Euphrasia genus and its methanolic fractions have been evaluated for their antioxidant and anti-inflammatory activities (3). The biological activity of aqueous tinctures and alcohol extracts are based on the accumulation of highly active compounds like iridoids, flavonoids, phenolic acids or etheric oils $(1,2,5)$. We may suppose that $E$. officinalis L. preparations for the treat- ment of eye disorders are generally based on their antioxidant, anti-inflammatory and regenerative properties. Moreover, as full extracts are used on the principle of the historical tradition, selective extracts are employed mainly for reason of their specific activity (11). Accordingly, in this study, we analyzed the cytotoxic, antioxidant and immunomodulatory effects of ethanol, ethyl acetate and heptane extracts of $E$. officinalis L. on human corneal epithelial (10.014 pRSV-T) cells.

The aim of this study was to answer the question concerning the variety of biological effects of $E$. officinalis $\mathrm{L}$. extracts obtained using different solvents by in vitro tests on human corneal cells, and their potential medicinal properties/effects when used in the treatment of eye disorders.

\section{MATERIAL AND METHODS}

\section{Plant material}

Euphrasia herbs were harvested from the area of Górki Czechowskie (Lublin, Poland) on a sunny day in September 2009. 
A voucher specimen was deposited at the Department of Pharmaceutical Botany, Medical University, Lublin, Poland and was identified by professor T. Krzaczek (Medical University in Lublin). The plants were subsequently cleaned of any possible contaminants and dried at room temperature. After pulverization, the plant material underwent chromatographic analysis.

\section{Extracts preparation}

The materials for testing were the ethanol, ethyl acetate and heptane extracts, derived from the Euphrasia officinalis herb. Dried and pulverized material was weighed in portions of $5 \mathrm{~g}$ each, and then exhaustive extraction was carried out in an ultrasonic bath (Bandelin; Sonorex, Germany) (U-230, V 50/50Hz; and -1.2 A, P-120/480W; $f-35 \mathrm{kHz}$; temp $20-80^{\circ} \mathrm{C}$ ).

The raw material underwent four-fold extraction under the following conditions:

1. 15 min extraction using $100 \mathrm{~mL}$ of ethanol $90 \%$ in temp. $45^{\circ} \mathrm{C}$

2. 15 min extraction using $100 \mathrm{~mL}$ of ethanol $90 \%$

3. $15 \mathrm{~min}$ extraction with $70 \mathrm{~mL}$ of ethanol $90 \%$

4. 15 min extraction with $70 \mathrm{~mL}$ of ethanol $90 \%$

Each time the extract was decanted from the raw material. After the extraction process, all four solutions were combined, then evaporated to dryness in an IKA RV 05-ST 1 rotary vacuum evaporator (IKA-Werke; Staufen, Germany) at $35^{\circ} \mathrm{C}$. The resulting dry residue was used in biological research tests. The process of preparing the ethyl acetate and heptane extracts of the Euphrasia officinalis herb proceeded similarly but using $100 \%$ solutions.

Part of the dry residue was dissolved in dimethylsulfoxide (DMSO) (Sigma; St. Louis, MO, USA) to obtain a concentration of $100 \mathrm{mg} / \mathrm{mL}$ (stock solution). The highest quantity of DMSO in the applied plant extract did not exceed $0.1 \%$. Such a concentration of DMSO in the culture medium has no influence on $10.014 \mathrm{pRSV}-\mathrm{T}$ cell viability, as was shown in our previous tests.

\section{Cell culture}

The human normal corneal cell line 10.014 pRSV-T (ATCC No. CRL-11515) was used. The cells were cultured as monolayers in 25 $\mathrm{cm}^{2}$ culture flasks (Nunc, Roskilde, Denmark) coated with PureCol ${ }^{\mathrm{TM}}$ ultrapure collagen (INAMED Biomaterials, Fremont, CA, USA) at $3.1 \mathrm{mg} / \mathrm{mL}$. The cell line was maintained in defined keratinocyteserum free medium (K-SFM) (Gibco) supplemented with $75 \mu \mathrm{g} / \mathrm{ml}$ endothelial cell growth factor (ECGF) (Sigma), $0.05 \mathrm{mg} / \mathrm{mL}$ bovine pituitary extract (BPE) (Gibco), $500 \mathrm{ng} / \mathrm{mL}$ hydrocortisone (Sigma), $0.0005 \mathrm{mg} / \mathrm{mL}$ bovine insulin (Gibco) and antibiotics $(100 \mathrm{U} / \mathrm{mL}$ penicillin, $100 \mu \mathrm{g} / \mathrm{mL}$ streptomycin) (Sigma, St Louis, MO, USA) at $37^{\circ} \mathrm{C}$ in a humidified atmosphere with $5 \% \mathrm{CO}_{2}$.

\section{Incubation of cells with Euphrasiae officinalis L. extracts}

For the purpose of the current experiments, the total number of cells was estimated by counting in a hemocytometer. A dose of 100 $\mu \mathrm{L}$ of cell suspension $\left(1 \times 10^{5}\right.$ cells $\left./ \mathrm{mL}\right)$ was added to the appropriate wells of 96-well flat-bottomed microtiter plates (MTT and NR methods). After $24 \mathrm{~h}$ of incubation, the medium was discarded and new medium was added, with appropriate concentrations of extracts. As controls, cells cultured in $100 \mu \mathrm{L}$ of medium were used, with the total cell number equivalent to these in the sample wells. A blank control consisted only of culture medium. The incubation was performed for a further $24 \mathrm{~h}$, with the cytotoxicity and anti-proliferative activity of extracts estimated by spectrophotometric methods (MTT and NR assays).

\section{Neutral Red (NR) uptake assay}

The NR cytotoxicity assay is based on the uptake and lysosomal accumulation of the supravital dye, Neutral Red. Dead or damaged cells do not take up the dye (12). Cells were grown in 96-well multiplates in $100 \mu \mathrm{L}$ of culture medium (K-SFM) with supplements and various concentrations of E. officinalis L. extracts $(25-125 \mu \mathrm{g} / \mathrm{mL})$. Subsequently, the medium was discarded and $0.4 \%$ NR (Sigma) solution medium was added to each well. The plate was incubated for $3 \mathrm{~h}$ at $37^{\circ} \mathrm{C}$ in a humidified $5 \% \mathrm{CO}_{2} / 95 \%$ air incubator. After incubation, the dye-containing medium was removed, cells were fixed with $1 \%$ $\mathrm{CaCl}_{2}$ in $4 \%$ paraformaldehyde, and thereafter the incorporated dye was solubilized using $1 \%$ acetic acetate in a $50 \%$ ethanol solution $(100 \mu \mathrm{L})$. The plates were gently shaken for $20 \mathrm{~min}$ at room temperature and the extracted dye absorbance was measured spectrophotometrically at $540 \mathrm{~nm}$.

\section{MTT assay}

MTT test is based on the conversion of a yellow tetrazolium salt by viable cells to purple crystals of formazan. The reaction is catalyzed by mitochondrial succinyl dehydrogenase. Cell sensitivity to $E$. officinalis L. extracts was determined in a standard spectrophotometric 3-(4.5-dimethylthiazole-2-yl)-2.5-diphenyltetrazolium bromide (MTT) assay. Cells grown in 96-well multiplates in $100 \mu \mathrm{L}$ of culture medium were incubated for $3 \mathrm{~h}$ with MTT solution $(5 \mathrm{mg} / \mathrm{mL}, 25 \mu \mathrm{l} /$ well) (Sigma). The yellow tetrazolium salt was metabolized by viable cells into purple formazan crystals. The crystals were solubilized overnight in a $10 \%$ sodium dodecyl sulfate (SDS) in $0.01 \mathrm{M} \mathrm{HCl}$. The product was quantified spectrophotometrically by absorbance measurements at $570 \mathrm{~nm}$ using an E-max Microplate Reader (Molecular Devices Corporation; Menlo Park, CA, USA).

\section{DPPH• free radical scavenging test}

The free radical scavenging activity of extracts was measured by the 1.1-diphenyl-2-picrylhydrazyl (DPPH') assay. This method is based on the ability of antioxidants to reduce the stable dark violet radical DPPH' (Sigma) to the yellow diphenyl-picrylhydrazine. Briefly, $100 \mu \mathrm{L}$ of DPPH ${ }^{*}$ solution $(0.2 \mathrm{mg} / \mathrm{mL}$ in ethanol $)$ was added to $100 \mu \mathrm{L}$ of extract concentrations $(25-125 \mu \mathrm{g} / \mathrm{mL})$ and standards. Trolox (Sigma) at increasing concentrations (1-50 $\mu \mathrm{g} / \mathrm{mL})$ was used as a reference for the free radical scavenging activity. After $20 \mathrm{~min}$ of incubation at room temperature, the absorbance of the solution was measured at $515 \mathrm{~nm}$. A lower absorbance indicates greater free 
radical scavenging activity of the extracts. The activity of each extract was determined by comparing its absorbance with that of a blank solution (reagents without extract) and standard.

The capability to scavenge DPPH' radical was calculated by the following formula:

DPPH' scavenging effect $(\%)=\left[\left(X_{\text {control }}-X_{\text {extract }} / X_{\text {control }}\right) \times 100\right]$

Where $\mathrm{X}_{\text {control }}$ is the absorbance of the control and $\mathrm{X}_{\text {extract }}$ is the absorbance in the presence of extracts (13).

\section{Ferric-reducing antioxidant power assay}

Each extract concentration was dissolved in Milli-Q water, mixed with an equal volume of $0.2 \mathrm{M}$ sodium phosphate buffer $(\mathrm{pH}$ 6.6 ) and $1 \%$ potassium ferricyanide. The mixture was incubated for $30 \mathrm{~min}$ at $37^{\circ} \mathrm{C}$. Then, $10 \%$ trichloroacetic acid (w/v) was added and the mixture was centrifuged at $1000 \mathrm{~g}$ for $5 \mathrm{~min}$. $1 \mathrm{~mL}$ of the upper layer was mixed with an equal volume of Milli-Q water and $0.1 \%$ ferric chloride. The absorbance was measured at $700 \mathrm{~nm}$ using an E-max Microplate Reader (Molecular Devices Corporation, Menlo Park, CA, USA). Ascorbic acid was used as the positive control.

\section{Nitric oxide (NO) measurement}

Nitrate, a stable end product of $\mathrm{NO}$, was determined in culture supernatants by a spectrophotometric method based on the Griess reaction. Briefly, $100 \mu \mathrm{L}$ of supernatant was placed in 96-well flatbottomed plates in triplicate and incubated with $100 \mu \mathrm{L}$ of Griess reagent (1\% sulfanilamide/0.1\% $\mathrm{N}$-(1-naphthyl) ethylenediamine dihydrochloride) (Sigma) in $3 \% \mathrm{H}_{3} \mathrm{PO}_{4}$ ( $\mathrm{POCH}$ Gliwice, Poland) at room temperature for $10 \mathrm{~min}$. The optical density was measured at $550 \mathrm{~nm}$ using a microplate reader (Molecular Devices Corp., Emax, Menlo Park, CA, USA). A standard curve was achieved using 0.5-25 $\mu \mathrm{M}$ sodium nitrite $\left(\mathrm{NaNO}_{2}\right)$ for calibration.

\section{ELISA assay}

The levels of human IL-1 $\beta$, IL-6, TNF- $\alpha$ and IL-10 were tested immunoenzymatically (ELISA) using commercially available kits (Diaclone, Besancon Cedex, France) according to the manufacturer's instructions. The optical density at $450 \mathrm{~nm}$ with a correction wavelength of $570 \mathrm{~nm}$ was determined for each ELISA sample using a microplate reader. The IL- $1 \beta$, IL- 6 , TNF- $\alpha$ and IL- 10 concentrations were calculated on the basis of a standard curve. The detection limits were $7 \mathrm{pg} / \mathrm{mL}$ (IL-1 $\beta$ ), $2 \mathrm{pg} / \mathrm{mL}$ (IL-6), $8 \mathrm{pg} / \mathrm{mL}$ (TNF- $\alpha$ ) and $5 \mathrm{pg} /$ $\mathrm{mL}$ (IL-10).

\section{Labeling cytoskeleton F-actin}

Cells were incubated in 4-well Lab-Tek chamber slides (Nunc. Roskilde, Denmark) filled with $1 \mathrm{ml}$ of culture medium supplemented with plant extracts. After incubation, cells were rinsed with K-SFM medium and exposed to paraformaldehyde (10\%, v/v) solution for $20 \mathrm{~min}$, rinsed three times in PBS, exposed to Triton X-100 $(0.2 \%, \mathrm{v} / \mathrm{v})($ Sigma) solution for $5 \mathrm{~min}$ and rinsed three times with PBS. 0.5 mL PBS containing tetramethyl-rhodamine-isothiocyanatephalloidin (TRITC-phalloidin, $1 \mu \mathrm{g} / \mathrm{mL}$ ) (Sigma) was added to each well and incubated in the dark at $37^{\circ} \mathrm{C} / 5 \% \mathrm{CO}_{2}$ for $30 \mathrm{~min}$. Cell observation was conducted under a fluorescent microscope (Olympus, BX51, Tokyo, Japan). Quantitative analysis of fluorescent images was performed using an AnalySIS imaging software system.

\section{Statistical analysis}

The biological experiments were repeated three times. The data were analyzed using one-way ANOVA followed by Dunnett's multiple comparison post-hoc test. Only results with a significance of $\mathrm{p} \leq 0.05$ were considered significant.

\section{RESULTS}

The toxicity, anti-proliferative and reactive oxygen species (ROS) scavenging activity, but also pro-inflammatory (IL-1 $\beta$, IL-6 and TNF- $\alpha$ ) and anti-inflammatory (IL-10) cytokine production in human normal corneal (10.014 pRSV-T) cells were analyzed after incubation with the ethanol, ethyl acetate and heptane extracts of E. officinalis L.. Moreover, the level of nitric oxide (NO) released by corneal cells during incubation with eyebright extracts was tested.

\section{Toxicity (NR test) and anti-proliferative activity (MTT test) of $E$. officinalis L. extracts}

The viability of 10.014 pRSV-T cells after $24 \mathrm{~h}$ of incubation with the plant extracts was estimated using NR uptake or MTT assays. The NR test showed no toxicity of ethanol and a limited (viability above $80 \%$ at $125 \mu \mathrm{g} / \mathrm{mL}$ ) effect of the ethyl acetate extract on corneal cells. The heptane extract began to be toxic at concentrations exceeding $90 \mu \mathrm{g} / \mathrm{mL}$. Cell viability, based on lysosomal accumulation of the NR dye, was less than $80 \%$ (Figure 1a).

The results were confirmed by the succinyl dehydrogenase activity (MTT) test. No anti-proliferative activity of either the ethanol or ethyl acetate extracts on cells was observed. The heptane extract at concentrations greater than $25 \mu \mathrm{g} / \mathrm{mL}$ systematically reduced 10.014 pRSV-T cell mitochondrial metabolism and, as a consequence, proliferation and viability decreased to about $40 \%$ at concentrations greater than $75 \mu \mathrm{g} /$ $\mathrm{mL}$ (Figure $1 \mathrm{~b}$ ). The $\mathrm{IC}_{50}$ value, indicating the concentration of eyebright heptane extract that inhibited the viability of corneal cells by $50 \%$, was $72.77 \mu \mathrm{g} / \mathrm{mL}$.

\section{Free radical scavenging activity of the extracts (DPPH test)}

The reactive oxygen species (ROS) reducing action of Euphrasia extracts is presented in Table 1. The experiments were performed using the DPPH test. The methanol extract showed the highest scavenging activity. The effect was extract concentration-dependent with the highest effect observed at the maximum dose used $(125 \mu \mathrm{g} / \mathrm{mL})$, and was $65.9 \%$ higher 
a

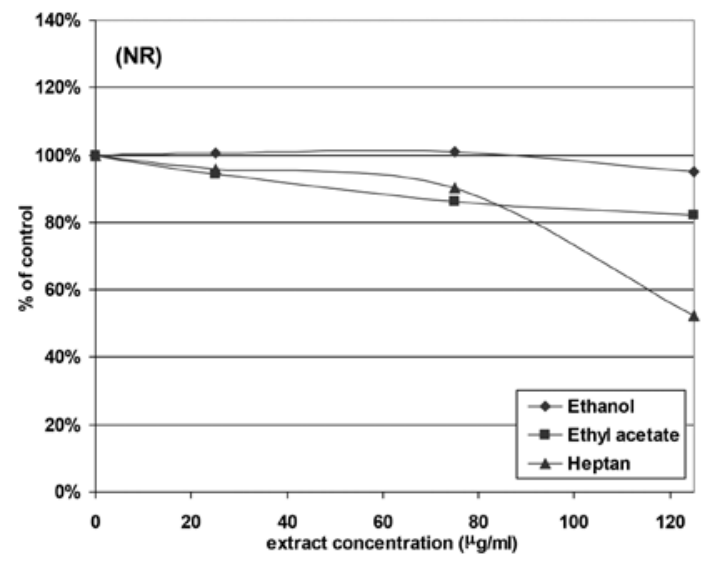

b



FIG. 1. a, b. The effect of $24 \mathrm{~h}$ treatment of $10.014 \mathrm{pRSV}-\mathrm{T}$ with methanol, ethyl acetate and heptane extracts of E. officinalis L. The Neutral Red assay (NR) (a) and MTT assay (b). The results are presented as a percentage of the control, arbitrarily set to $100 \%$. The figure shows an average of three independent experiments

TABLE 1. DPPH free radical scavenging activity (\%). The \% of reduced DPPH radicals by Euphrasia officinalis L. extracts is compared to the control $(0 \%$ reduction)

\begin{tabular}{lccc}
\hline Extract & $\begin{array}{c}\text { Extract } \\
\text { concentration } \\
(\mu \mathrm{g} / \mathrm{mL})\end{array}$ & $\begin{array}{c}\text { \% reduction as } \\
\text { compared } \\
\text { to control } \\
(0 \% \text { reduction })\end{array}$ & $\begin{array}{c}\text { Reduction value, } \\
\text { which correspond } \\
\text { to the following } \\
\text { Trolox concentration } \\
(\mu \mathrm{g} / \mathrm{mL})\end{array}$ \\
\hline Ethanol & 25 & $5.76 \pm 0.27$ & 1.898 \\
& 75 & $34.54 \pm 0.6$ & 12.55 \\
Ethyl acetate & 125 & $65.86 \pm 0.54$ & 24.18 \\
& 25 & $4.28 \pm 0.27$ & 1.336 \\
Heptane & 75 & $20.41 \pm 0.74$ & 7.334 \\
& 125 & $39.09 \pm 0.47$ & 14.24 \\
& 25 & 0 & 0 \\
& 75 & 0 & 0 \\
\hline
\end{tabular}

TABLE 2. Ferric-reducing antioxidant power assay. The \% of reduced ferric ions by Euphrasia officinalis L. extracts is compared to the control ( $0 \%$ reduction)

\begin{tabular}{lccc}
\hline Extract & $\begin{array}{c}\text { Extract } \\
\text { concentration } \\
(\mu \mathrm{g} / \mathrm{mL})\end{array}$ & $\begin{array}{c}\text { reduction } \\
\left(\mathrm{Fe}^{3+} \rightarrow \mathrm{Fe}^{2+}\right) \\
\text { as compared } \\
\text { to control } \\
(0 \% \text { reduction })\end{array}$ & $\begin{array}{c}\text { Reduction value, } \\
\text { which correspond } \\
\text { to the following } \\
\text { ascorbic acid } \\
\text { Ethanol }\end{array}$ \\
& 25 & $56.18 \pm 0.54$ & 10.95 \\
& 75 & $173.66 \pm 1.86$ & 33.86 \\
Ethyl acetate & 125 & $293.82 \pm 3.55$ & 57.29 \\
& 25 & $46.77 \pm 0.62$ & 9.12 \\
Heptane & 75 & $125.27 \pm 1.39$ & 24.42 \\
& 125 & $213.71 \pm 1.61$ & 41.67 \\
& 25 & $4.57 \pm 0.54$ & 0.89 \\
& 75 & $10.48 \pm 1.03$ & 2.04 \\
& 125 & $14.52 \pm 1.39$ & 2.83 \\
\hline
\end{tabular}

than the control value. The $\mathrm{IC}_{50}$ value was $99.68 \mu \mathrm{g} / \mathrm{mL}$. When compared to the Trolox standard activity, it was the equivalent of $24.2 \mu \mathrm{g} / \mathrm{mL}$ of the synthetic vitamin concentration. The reduction results were lower by almost half for the ethyl acetate extracts. The heptane extract did not show DPPH reduction activity.

\section{Ferric-reducing antioxidant power assay}

The reduction results are presented in Table 2, and confirm the reductive activity of E. officinalis L. extracts, as was shown in DPPH test. Relationships among the analyzed parameters were also similar. The methanol extract showed the highest activity. At the highest concentration $(125 \mu \mathrm{g} / \mathrm{mL})$, the reduction was $293.8 \%$ higher than the control value. When compared to ascorbic acid which was used as a positive control, it was equivalent to $57.3 \mu \mathrm{g} / \mathrm{mL}$ of this vitamin concentration. The activity of the ethyl acetate extract was slightly lower. However, the heptane extract, in contrast to the results obtained in the DPPH test, showed reductive activity but at a very low level. At the highest extract concentration $(125 \mu \mathrm{g} / \mathrm{mL})$, the reduction value was $14.5 \%$ higher compared to the control.

\section{Nitric oxide (NO) production}

In this test, we measured $\mathrm{NO}$ end-products $\left(\mathrm{NO}_{2}\right.$ and $\left.\mathrm{NO}_{3}\right)$, termed NOx. The control level was $0.973 \mu \mathrm{M}$. Two concentrations of extracts were used: $8 \mu \mathrm{g} / \mathrm{mL}$ and $20 \mu \mathrm{g} / \mathrm{mL}$. We found that the lower ethanol extract concentration reduced the NOx level to a greater extent than the higher one. However, all results were lower than the radical level obtained in the control. Inversely, a higher concentration of the ethyl acetate and heptane extracts led to stronger NOx reducing activity. Interestingly, $8 \mu \mathrm{g} / \mathrm{mL}$ of the ethyl acetate extract induced NOx production above the control level, but $20 \mu \mathrm{g} / \mathrm{mL}$ of the extract 
decreased the NOx level to below the control value. Similarly, heptane extract application in the cell culture medium led to a reduction in the NOx level below the control at both extract concentrations (Figure 2).

\section{ELISA tests \\ Pro-inflammatory cytokine levels}

\section{IL-1 $\beta$}

Non-treated $10.014 \mathrm{pRSV}-\mathrm{T}$ cells released $18.81 \mathrm{pg} / \mathrm{mL}$ IL-1 $\beta$, which was taken as the control level. After Euphrasia extract application, a decrease in the cytokine level was observed. However, the higher the concentration of ethanol extract, the lesser the decrease in the IL- $1 \beta$ level. On the other hand, higher concentrations of the ethyl acetate and heptane extracts resulted in lower IL- $1 \beta$ production by $10.014 \mathrm{pRSV}-\mathrm{T}$ cells (Figure 3a).

\section{IL-6}

The control level of IL- 6 produced by the analyzed corneal cells was $17.06 \mathrm{pg} / \mathrm{mL}$. After eyebright extract application to the culture medium, we observed decreased production of IL6, which was extract concentration-dependent (Figure 3b).

\section{TNF- $\alpha$}

The control level of TNF- $\alpha$ in 10.014 pRSV-T cells medium was found to be $17.46 \mathrm{pg} / \mathrm{mL}$ after $24 \mathrm{~h}$ of culture. Euphrasia extract addition to the 10.014 pRSV-T cells culture led to the inhibition of TNF- $\alpha$ production by these cells. The exception was $8 \mu \mathrm{g} / \mathrm{mL}$ of the heptane extract, which in this case induced TNF- $\alpha$ production to a level of $24.98 \mathrm{pg} / \mathrm{mL}$ (Figure 3c).

\section{Anti-inflammatory cytokine levels}

\section{IL-10}

Non-treated corneal cells produced $5.142 \mathrm{pg} / \mathrm{mL}$ of IL-10. The higher ethanol extract concentration $(20 \mu \mathrm{g} / \mathrm{mL})$ led to greater IL-10 production, while higher concentrations of the ethyl acetate and heptane extracts decreased IL-10 levels. Moreover, $20 \mu \mathrm{g} / \mathrm{mL}$ of the ethanol extract induced IL-10 production over the control level (Figure 3d).

\section{Cytoskeleton F-actin filament organization}

F-actin filaments were analyzed using TRITC-phalloidin fluorescent staining method after $24 \mathrm{~h}$ of incubation of 10.014 pRSV-T cells with $20 \mu \mathrm{g} / \mathrm{mL}$ of the Euphrasia extracts. The control cells are shown in Figure 4. After incubation of the cells with the ethanol, ethyl acetate and heptane extracts of $E$. officinalis L., there were no cytoskeleton changes when compared to the control.

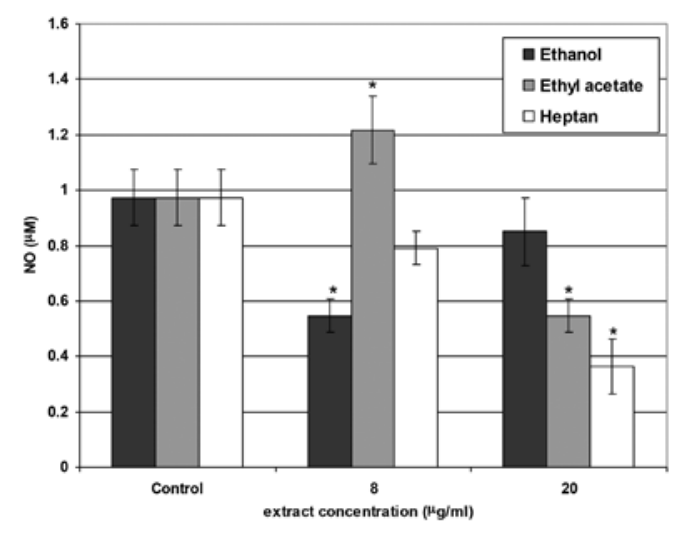

FIG. 2. Nitric oxide (NO) secretion in culture of 10.014 pRSV-T human normal corneal cells during $24 \mathrm{~h}$ of incubation with the methanol, ethyl acetate and heptane extracts of $E$. officinalis L. Two concentrations of the extracts were used: $8 \mu \mathrm{g} / \mathrm{mL}$ and $20 \mu \mathrm{g} / \mathrm{mL}$. Analysis was performed using the Griess method. Columns and bars show the mean \pm standard deviation $(n=3)$. * $p \leq 0.01$ - culture of corneal cells treated with plant extracts compared to the non-treated culture control

\section{DISCUSSION}

Cornea and of conjunctiva external surfaces are formed by specialized epithelium which, however, come from different precursor cells. Both epithelia are of the scaly, non-keratinized type formed from adherent layers of cells that continually renew and regenerate themselves (14). The eye surface is naturally exposed to various organic and inorganic substances, which may lead to toxic injury of this organ. The corneal epithelial layer, a barrier separating deeper parts of the eye from the external environment, is most important and sensitive. The cornea is covered by a squamous epithelium possessing intense regenerative potential, thus enabling fast restoration of the damaged eye surface. Corneal cells are the most external part of the eye and are therefore liable to suffer an injury, and so are very useful in toxicological diagnosis in vitro (15). Currently, due to ease to access, ease of culture and repeatable results, cell lines rather than primary cells isolated from the whole organ are most often used to this end. In the past, introducing new substances for therapy of the eye required that these substances should be tested for toxicity against the corneal layer. Currently, it is accepted that herbal preparations used in traditional ocular medicine may act beneficially and exert limited side effects $(16,17)$. One of the most widely used but not completely characterized herbs is Euphrasia officinalis L. It is used externally in the treatment of conjunctivitis or palpebral margin inflammation $(5,17)$. Moreover, water extracts of Herba Euphrasie show anti-inflammatory, antimicrobial, or immunomodulatory effects (5). These features are associated with the presence of many biologically active substances in this herb. It was revealed that the active 


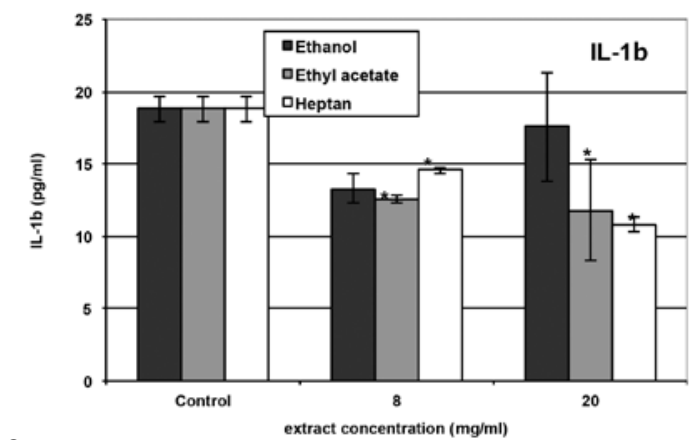

c

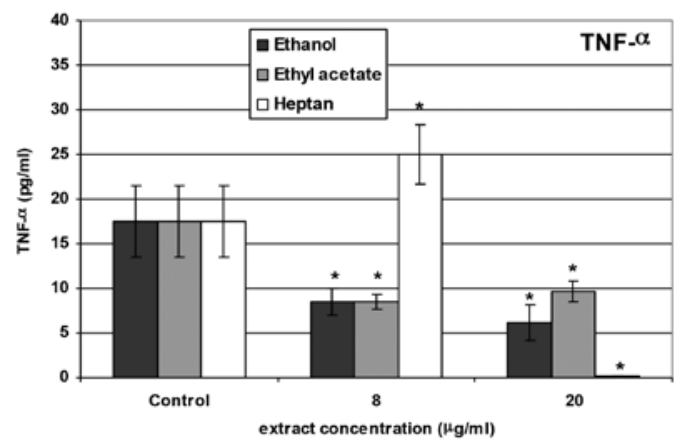

b

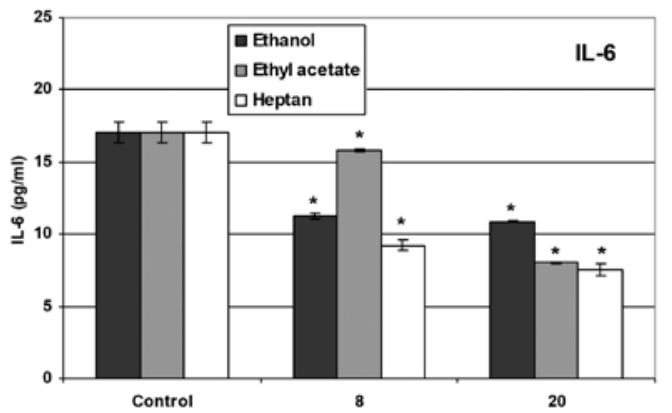

d extract concentration $(\mu \mathrm{g} / \mathrm{ml})$

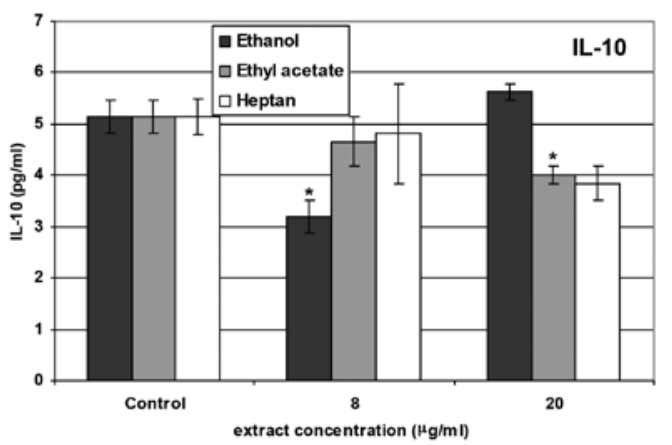

FIG. 3. a-d. IL-1 $\beta$ (a), IL-6 (b), TNF- $\alpha$ (c) and IL-10 (d) secretion as assessed by ELISA in the culture of 10.014 pRSV-T human normal corneal cells after $24 \mathrm{~h}$ of incubation with the methanol, ethyl acetate and heptane extracts of $E$. officinalis $\mathrm{L}$. Two concentrations of the extracts were used: $8 \mu \mathrm{g} / \mathrm{mL}$ and $20 \mu \mathrm{g} / \mathrm{mL}$. ${ }^{*} p \leq 0.01$ - culture of corneal cells treated with plant extracts compared to the non-treated culture control

substances of the Euphrasia herb include iridoglicozoids (aucubin), tannins, phenolic acids, etheric oils, resin substances and flavonoids $(2,5,18,19)$.

In the present study, we show that the ethanol and ethyl acetate extracts of $E$. officinalis $\mathrm{L}$. are not toxic to human corneal cells even at a concentration of $125 \mu \mathrm{g} / \mathrm{mL}$. However, mixtures of fractions obtained after heptane extraction were toxic to cells when the concentration exceeded $75 \mu \mathrm{g} / \mathrm{mL}$, while cellular mitochondrial metabolism was significantly limited at a concentration of only $25 \mu \mathrm{g} / \mathrm{ml}$. These results suggest that the solvent used during extraction is very important, and fractions of Herba Euphrasie obtained using non-polar solvents may exert undesirable effects on the eyes. The present results are in agreement with the thesis of Ríos and Recio (7), who showed that the antimicrobial and medicinal activity of plant extracts is most interesting at concentrations lower than $100 \mu \mathrm{g} / \mathrm{mL}$.

The ethanol and ethyl acetate extracts had strong free radical scavenging activity, while the heptane extract did not show any essential reducing effects. The result with the latter may be due to differences in polarity of the working medium (polar) and non-polar extracts. As a consequence, interactions of DPPH radicals with extract scavenger molecules may have been hampered. Therefore, Fe reduction tests were also per- formed, which confirmed the results of the DPPH test, showing very low activity of the heptane extract. Extracts obtained using a polar solvent (ethanol) increased corneal cell NOx production, while the inverse, i.e. extracts obtained with ethyl acetate and heptane, decreased the NOx level. These effects

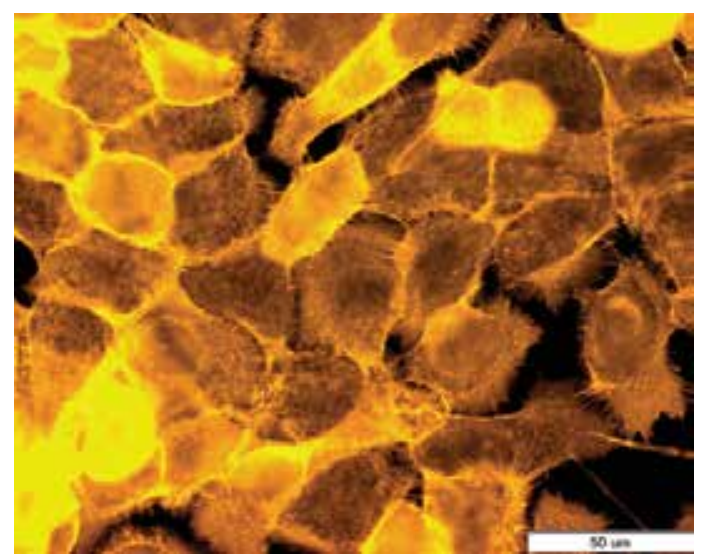

FIG. 4. Cytoskeleton organization and reciprocal, direct interactions among human normal corneal cells (10.014 pRSV-T). Control sample. Fluorescent staining of cells using TRITC-phalloidin dye. Magnification 400x. Bar $50 \mu \mathrm{m}$ 
were extract concentration-dependent. The results may suggest that the toxicity caused by free radicals can be reduced using eyebright extracts. Extract concentration-dependent changes in the NOx level were also significant. Therefore, at low NOx concentrations, important positive roles in the maintenance of eye surface health may be observed. This may be a beneficial effect in some chronic eye diseases such as dry eye or ocular allergies. These diseases have been demonstrated to cause inflammatory reactions, further damaging the corneal epithelium (20-22). NO is a free radical at high concentrations, and prolonged exposure exerts inhibitory activity on several enzymes and cell structures, i.e. NO becomes cytotoxic or cytostatic. It should be also mentioned that the important relationship between ROS and NO is an oxidative reaction forming more active intermediates (RNOS) such as peroxynitrates. These are capable of toxic nitrosylation and/or nitration of some amino acid residues of proteins (23). Thus, prolonged exposure of cells to substances upsetting the equilibrium between ROS and NO levels may be detrimental. As a consequence, it would not be enough to analyze the antioxidant activity of herbs on typical reactive oxygen species like superoxide $\left(\mathrm{O}_{2}^{-}\right)$, alkoxyl ( $\left.\mathrm{RO}\right)$, hydroxyl $(\mathrm{OH})$ or peroxyl (ROO), but an important radical like NO should also be evaluated (24).

In our experiments, the ethanol (at low concentrations) and ethyl acetate extracts were the most useful E. officinalis L. extracts for supplemental clinical ocular medicine due to their effects on the free radical balance. It has been shown that many substances and extracts from botanical sources and medicinal herbs exert an influence on the NO signaling pathway. Among them are saponin, polyphenols, procyanidins, oleic acids, flavonoids, alkaloids and tannins $(23,25)$. A substantial body of evidence supports the view that various herb-derived substances exert significant anti-inflammatory effects. Therefore, they may be potentially used in therapeutic supplementation, e.g. in ocular inflammation $(2,5)$. It has been shown that flavonoids and polyphenols possess an inflammation reducing effect. Their anti-inflammatory properties are manifested mainly through the modulation of the cytokine network. $\mathrm{Cy}-$ tokines are a group of multifunctional substances involved in immunological processes. One of the classifications distinguishes pro- and anti-inflammatory cytokines; IL-1 $\beta$, IL-6 or TNF- $\alpha$ represent the former group while e.g. IL-10 the latter (18). In our experiments, we show that E. officinalis L. extract application to $10.014 \mathrm{pRSV}-\mathrm{T}$ cells generally decreased pro-inflammatory cytokine levels. Inhibition of inflammation should be considered to be a positive therapeutic effect, considering the fact that prolonged inflammation is the result of many pathologies. In this context, anti-inflammatory IL10 is also very important. We show, however, that eyebright extracts also simultaneously decreased anti-inflammatory cytokine production. It has to be considered that cytokines in their biological network may mutually modulate their production. Therefore, it was important to analyze both pro- and anti-inflammatory cytokines. On the basis of our study, we may conclude that either both groups of cytokines reciprocally modulate their own production or plant extracts generally decrease cytokine genes expression. Moreover, it should be mentioned that, in our study, the IL-10 level was mostly connected with IL-1 $\beta$ production. This effect should be examined as mutual balance maintenance. Generally, E. officinalis L. extracts did not induce an inflammatory state, measured by pro-inflammatory cytokine levels, in human corneal cell culture. Therefore, we can assume that the cytokines released by corneal cells treated with E. officinalis L. extracts in our tests exert immunomodulatory activity rather than typical anti- or pro-inflammatory properties.

In conclusion, we suggest that performing a comprehensive analysis of plant extract activity on cultured cells should be completed in least three steps, i.e. toxicity analyses, reactive oxygen species scavenging effects and the influence on the cytokine network (immunomodulation). Considering these points, we show that the ethanol and ethyl acetate extracts of E. officinalis L. can be satisfactorily used as a supplemental therapy in human corneal disorders. The heptane extract should not be recommended. Generally, one should strive to standardize herbal medicines which are used in ocular ailment therapies, mainly through decreasing their toxic side effects and demonstrating their safety for patients.

\section{Ethics Committee Approval: N/A.}

Informed Consent: N/A.

Peer-review: Externally peer-reviewed.

Author contributions: Concept - R.P., A.W.; Design - R.P.; Supervision - R.P., A.W.; Resource - R.P., A.W., R.R.; Materials - R.P., A.W.; Data Collection\&/or Processing - R.P., A.W., P.N.; Analysis\&/or Interpretation - R.P.; Literature Search - R.P., P.N.; Writing - R.P.; Critical Reviews - A.W., R.R.

Conflict of Interest: No conflict of interest was declared by the authors.

Financial Disclosure: The authors declared that this study has received no financial support.

\section{REFERENCES}

1. Petrichenko VM, Sukhinina TV, Babiyan LK, Shramm NI. Chemical composition and antioxidant properties of biologically active compounds from Euphrasia brevipila. Pharm Chem J 2006;40:312-6. [CrossRef]

2. Stoss M, Michels C, Peter E, Beutke R, Gorter RW. Prospective cohort trial of Euphrasia single-dose eye drops in conjunctivitis. J Altern Complement Med 2000;6:499-508. [CrossRef]

3. Blazics B, Alberti A, Kéry A. Antioxidant activity of different phenolic fractions separated from Euphrasia rostkoviana Hayne. Acta Pharm Hung 2009;79:11-6.

4. Citarasu T. Herbal biomedicines: a new opportunity for aquaculture industry. Aquacult Int 2010;18:403-14. [CrossRef] 
5. Kozłowski J, Krajewska A. Ziele świetlika jako leczniczy surowiec roślinny. Farm Pol 1982;38:471-4 (in polish).

6. Porchezhian E, Ansari SH, Shreedharan NKK. Antihyperglycemic activity of Euphrasia officinale leaves. Fitoterapia 2000;71:522-6. [CrossRef]

7. Ríos JL, Recio MC. Medicinal plants and antimicrobial activity. $J$ Ethnopharmacol 2005;100:80-4. [CrossRef]

8. Trovato A, Monforte MT, Forestieri AM, Pizzimenti F. In vitro antimycotic activity of some medicinal plants containing flavonoids. Boll Chim Farm 2000;139:225-7.

9. Dharma P, Singh G. A Review of Plant Species Used to Treat Conjunctivitis. Review article. Phytother Res 2002;16:1-22. [CrossRef]

10. Bielory L, Heimall J. Review of complementary and alternative medicine in treatment of ocular allergies. Curr Opin Allergy Clin Immunol 2003;5:395-9. [CrossRef]

11. Aburjai T, Natsheh FM. Plants used in cosmetics. Phytother Res 2003;17:987-1000. [CrossRef]

12. Ganbold M, Barker J, Ma R, Jones L, Carew M. Cytotoxicity and bioavailability studies on a decoction of Oldenlandia diffusa and its fractions separated by HPLC. J Ethnopharmacol 2010;131:396-403. [CrossRef]

13. Paduch R, Matysik G, Wójciak-Kosior M, Kandefer-Szerszeń M, Skalska-Kamińska A, Nowak-Kryska M, et al. Lamium album extracts express free radical scavenging and cytotoxic activities. Polish $J$ Environ Stud 2008; 17:569-80

14. Revoltella RP, Papini S, Rosellini A, Michelini M. Epithelial stem cells of the eye surface. Cell Prolif 2007;40:445-61. [CrossRef]

15. Wylęgała E, Dobrowolski D, Nowińska A, Tarnawska D. Anterior segment optical coherence tomography in eye injuries. Graefes Arch Clin Exp Ophthalmol 2009;247:451-5. [CrossRef]
16. Chana HS, Schwab L, Foster A. With an eye to good practice. Traditional healers in rural communities. World Health Forum 1994;15:144-6.

17. West AL, Fetters MD, Hemmila MR, Gorenflo DW, Kiyota A, Moroi-Fetters S. Herb and vitamin supplementation use among a general ophthalmology practice population. Am J Ophthalmol 2005;139:522-9. [CrossRef]

18. Calixto JB, Campos MM, Otuki MF, Santos ARS. Anti-inflammatory compounds of plant origin. Part II. Modulation of pro-inflammatory cytokines, chemokines and adhesion molecules. Planta Med 2004;70: 93-103. [CrossRef]

19. Shestakova TS, Petrichenko VM, Sukhinina TV. Elemental composition of Euphrasia brevipila herbs and extracts. Pharm Chem J 2008;42: 460-2. [CrossRef]

20. Baudouin C. The pathology of dry eye. Surv Ophthalmol 2001;45 (Suppl. 2):S211-20. [CrossRef]

21. Luo L, Li DQ, Doshi A, Farley W, Corrales RM, Pflugfelder SC. Experimental dry eye stimulates production of inflammatory cytokines and MMP-9 and activates MAPK signaling pathways on the ocular surface. Invest Ophthalmol Vis Sci 2004;45:4293-301. [CrossRef]

22. Yeh S, Song XJ, Farley W, Li DQ, Stern ME, Pflugfelder SC. Apoptosis of ocular surface cells in experimentally induced dry eye. Invest $O p h$ thalmol Vis Sci 2003;44:124-9. [CrossRef]

23. Achike FI, Kwan Ch-Y. Nitric oxide, human diseases and the herbal products that affect the nitric oxide signalling pathway. Clin Exp Pharmacol Physiol 2003;30:605-5. [CrossRef]

24. Kim PKM, Zamora R, Petrosko P, Billiar TR. The regulatory role of nitric oxide in apoptosis. Int Immunopharmacol 2001;1:1421-41. [CrossRef]

25. Schmitt ChA, Dirsch VM. Modulation of endothelial nitric oxide by plant-derived products. Nitric Oxide 2009;21:77-91. [CrossRef] 